\section{Hepatitis B in a West Indian population in the United Kingdom}

The prevalence of markers of hepatitis B virus infection shows considerable geographic variation, often being high in tropical areas where the standard of living is low. While the high prevalence in the far east is maintained by vertical transmission from mother to baby in the perinatal period, ${ }^{1}$ in Africa infection is usually transmitted horizontally during infancy. ${ }^{2}$

In the West Indies the prevalence of carriage of hepatitis B surface antigen ( $\mathrm{HBsAg}$ ) is $0-4 \cdot 1 \%,{ }^{34}$ varying between islands and according to the sensitivity of the test used, but we are unaware of any report on prevalence
Indians and that environmental factors in the tropics may be more important.

1 Stevens CE, Palmer Beasley R, Tsui J, Lee WC. Vertical transmission of hepatitis B antigen in Taiwan. N Englf Med 1975;292:771-4.

2 Whittle HC, Bradley AK, McLauchlan K, et al. Hepatitis B virus infection in two Gambian villages. Lancet 1983;i:1203-6.

3 Hull B, Spence L, Williams MC. Hepatitis B in Trinidad. West Indian Med $\mathcal{J}$ 1978;27:31-5.

4 Mazzur S, Nath N, Fang C, et al. Distribution of hepatitis B virus (HBV) markers in blood donors of 13 western hemisphere countries: proceedings of the Red Cross Latin American hepatitis B workshop. Bull Pan Am Health Organ 1980;14:44-51.

5 Barbara JAJ, Howel DR, Cleghorn TE, Cameron CH, Briggs M, Dane DS. A comparison of different methods of screening blood donations for HBsAg. Vox Sang 1977;32:4-9.

(Accepted 28 October 1985)

Hepatitis $B$ virus (HBV) markers in native West Indians, first generation West Indians born in Britain, and white patients

\begin{tabular}{|c|c|c|c|c|c|c|}
\hline \multirow[b]{2}{*}{ Ethnic group } & \multirow{2}{*}{$\begin{array}{l}\text { Country of } \\
\text { birth }\end{array}$} & \multirow{2}{*}{$\begin{array}{c}\text { Mean } \\
\text { (SD) age } \\
\text { (years) }\end{array}$} & \multicolumn{3}{|c|}{ No (\%) positive for: } & \multirow{2}{*}{$\begin{array}{c}\text { (\%) Positive } \\
\text { for } \geqslant 1 \text { HBV } \\
\text { marker }\end{array}$} \\
\hline & & & HBsAg & HBsAb & HBcAb & \\
\hline $\begin{array}{l}\text { Negro (West Indian) } \\
\text { Negro (West Indian) } \\
\text { White }\end{array}$ & $\begin{array}{c}\text { West Indies } \\
\text { United Kingdom } \\
\text { United Kingdom }\end{array}$ & $\begin{array}{l}33 \cdot 0(8 \cdot 9) \\
22 \cdot 4(5 \cdot 1) \\
27 \cdot 8(8 \cdot 0)\end{array}$ & $\begin{array}{l}8 / 195(4 \cdot 1) \\
1 / 259(0 \cdot 4) \\
0 / 180\end{array}$ & $\begin{array}{c}28 / 195(14 \cdot 4) \\
6 / 259(2 \cdot 3) \\
5 / 180(2 \cdot 8)\end{array}$ & $\begin{array}{l}2 / 43(4 \cdot 7) \\
0 / 44\end{array}$ & $\begin{array}{l}23 \\
2 \cdot 7 \\
2 \cdot 8\end{array}$ \\
\hline
\end{tabular}

among West Indians in the United Kingdom. To assess the need for screening for markers of hepatitis B virus in this group we determined the prevalence among West Indians and their descendants attending a department of genitourinary medicine in the district of Lambeth.

\section{Methods and results}

Serum samples were collected from 454 heterosexual West Indian negroes (195 born in the West Indies and 259 first generation, born in Britain of West Indian descent) and 180 white heterosexuals attending the department of genitourinary medicine at this hospital during February and March 1985. Each was tested for HBsAg by radioimmunoassay (Ausria II, Abbott, North Chicago, Illinois). Positive results were confirmed using $0 \cdot 1 \%$ modified reverse passive haemagglutination, and these serum samples were then tested for hepatitis $B$ e antigen ( $\mathrm{HBeAg}$ ) and antibody (HBeAb) by radioimmunoassay. All samples negative for HBsAg were tested for antibody to surface antigen (HBsAb). A sample with a result higher than a 50 IU control was considered to be positive for $\mathrm{HBs} \mathrm{Ab}$, as was one below the $50 \mathrm{IU}$ control but with a result above the cut off for the kit if it was positive for antibody (IgG) to core antigen (HBcAb). Random samples negative for other markers of hepatitis B virus were also tested for $\mathrm{HBcAb}$ by enzyme immunoassay (Corzyme, Abbott). Statistical analysis was by $\chi^{2}$ with Yates's correction.

The table compares the prevalence of markers of hepatitis B virus infection in native West Indians with that in first generation patients of West Indian descent born in Britain and white patients.

All markers were more common in native West Indians; $18.5 \%$ of this group were positive for surface markers compared with $2 \cdot 7 \%$ of first generation West Indians $(p<0.001)$. This difference persisted when men and women were analysed separately. Of the eight native West Indians $(4 \cdot 1 \%)$ with $\mathrm{HBsAg}$, two were $\mathrm{HBeAg}$ positive and five $\mathrm{HBeAb}$ positive, and one had no $\mathrm{HBe}$ markers. Only one first generation West Indian $(0 \cdot 4 \%)$ was positive for $\mathrm{HBsAg}(\mathrm{p}<0.025)$, and he was also $\mathrm{HBeAg}$ positive; he denied exposure to other risk factors for infection with hepatitis B virus. Although $\mathrm{HBsAg}$ was not detected in any white patients, five (two men and three women) had HBsAb. One of these subsequently gave a history of vaccination against hepatitis B virus, one was a soldier, and two had a history of jaundice.

\section{Comment}

These results confirm a relatively high prevalence of hepatitis $B$ infection in native West Indians but not in those of West Indian descent born in the United Kingdom. The $0.4 \%$ prevalence of carriage of $\mathrm{HBsAg}$ in the first generation West Indians approaches the $0.2 \%$ found in the indigenous British population,' indicating that this West Indian population adopted the British pattern of infection with hepatitis B virus over only one generation.

The results suggest that screening for $\mathrm{HBsAg}$ should be undertaken among native West Indians but not their descendants born in Britain. Such a policy would result in considerable financial saving in areas like Lambeth, which has a large West Indian population.

The disparity in the prevalence of hepatitis B virus markers between the native West Indian population and those born in Britain suggests that perinatal transmission from mother to baby is uncommon among West

\section{St Thomas's Hospital, London SE1 7EH}

M J GODLEY, MRCOG, senior registrar, department of genitourinary medicine P W LAIDLER, BSC, FIMLS, senior medical laboratory scientific officer department of clinical virology

J E BANATVALA, MD, FRCPATH, professor of clinical virology

Correspondence to: Dr Godley.

\section{Gall bladder contraction induced by cholecystokinin: bolus injection or infusion?}

Inducing contraction of the gall bladder has been reported to be of value in diagnosing biliary tract disorders. ${ }^{1}$ This procedure may facilitate the diagnosis of adenomyomatosis of the gall bladder, small gall stones, and biliary tract obstruction. Furthermore, measurement of gall bladder emptying in response to cholecystokinin may detect impaired emptying, as found in acalculous gall bladder disease. ${ }^{2}$ Both intravenous bolus injection and infusion of cholecystokinin have been used to induce gall bladder emptying. ${ }^{2}$ Since a rapid and strong contraction is needed we have compared the time course and degree of gall bladder contraction induced by bolus injection and infusion of similar amounts of cholecystokinin. We have also measured the plasma concentrations of cholecystokinin to obtain more insight into the mechanism of gall bladder contraction in response to this hormone.

\section{Subjects, methods, and results}

On two separate mornings six fasting healthy volunteers (four men) aged 20-27 years were studied in random order. On one morning cholecystokinin (Kabi Diagnostica, Studsvik, Sweden), 1 Ivy dog unit $/ \mathrm{kg}$, was administered by intravenous bolus injection over one minute, while on the other morning the same dose of cholecystokinin was administered as a continuous infusion over 60 minutes. Images of the gall bladder were obtained in duplicate by real time ultrasonography at $-5,0,5,10,20,30,40,50,60,75$, and 90 minutes. ${ }^{3}$ Gall bladder volumes were measured as described using a computer. ${ }^{3}$ Each time the gall bladder was imaged blood samples were taken for measurement of cholecystokinin. Plasma cholecystokinin concentrations were measured by a sensitive and specific radioimmunoassay employing antibody T204, which binds to all biologically active forms of the hormone. ${ }^{4}$ Results were expressed as the mean and one standard error of the mean. Statistical analysis was by Student's test for paired samples. Informed consent was obtained from all the subjects.

Both bolus injection and infusion of cholecystokinin induced significant decreases in gall bladder volume. Infusion of cholecystokinin induced a strong contraction reaching a plateau for at least $\mathbf{3 0}$ minutes, whereas after bolus injection maximum gall bladder contraction was followed rapidly by relaxation 